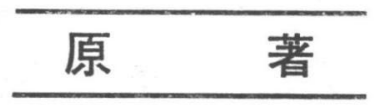

\title{
コンニャク精粉の血清脂質低下作用 \\ Hypolipemic Activity of Dietary Konjac Flour in the Rats
}

\author{
国立栄盖研究所 (The National Institute of Nutrition) \\ 印南敏 (Satoshi Innami) 津田 明子 (Akiko Tsuda) \\ 大谷八峯 (Yatsuho Ootani) 手塚 朋通 (Tomomichi Tezuka) \\ 帝京短期大学 (Teikyo Women College) \\ 永山 スミ子 (Sumiko Nagayama)
}

It has been reported that undigestible natural polysaccharides show a hypocholesterolemic effect when fed to rats and chicks fed a hypercholesterolemic diet.

In the present paper, the influence of Konjac flour (crude Konjac mannan obtained from the tubers of Amorphophallus Konjac, K. Koch) on lipid metabolism other than cholesterol was compared with two other polysaccharides. Weight gain, levels of triglyceride and phospholipid in serum and liver, and fecal lipids were measured when rats were fed on the low and high fat diet containing $5 \%$ of polysaccharides to the rats.

1) Serum triglyceride decreased significantly by the addition of Konjac flour in both low and high dietary fat levels. No hypotriglycedemic effect was seen by the addition of citrus pectin and Na. alginate. It seems that the hypotriglycedemic phenomenon of the latter two polysaccharides seen in the high fat level is mainly due to the decrease in food intake.

2) The increased fecal lipid excretion seen in the case of Konjac flour feeding indicates that Konjac flour inhibits fat absorption in the intestine in any way.

3) No change was seen in both hepatic triglyceride and phospholipid levels when Konjac flour was added to the diet.

4) The addition of undigestible polysaccharides to a high fat diet suggests the possibility of a more effective weight control.

\section{まえがき}

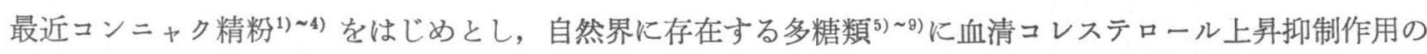
あることが見出され，動脈硬化症予防の可能性を提供するものとして注目を集めている。コンニャク精粉の場 合, その作用物質はコンニャク精粉中のダルコマンナン（一般的にコンニャクマンナンとも称する）と呼ばれ る人体内の消化酵素によっては消化されない難消化性多糖類であることが判明している ${ }^{10)}{ }^{11)}$ 。

ところで, 動脈硬化症には高コレステロール由来のみならず, 中性脂肪を主とする高脂血症由来のもののあ ることも知られている。

そこで，コンニャク精粉がコレステロール以外の血清脂質成分すなわち中性脂肪括よび燐脂質に対してどの ような影響を与えるかを知るために他の 2,3 の多糖類と比較検討した。 


\section{実 験 方 法}

$300 \mathrm{~g}$ 前後の Sprague Dawley 系の雄の成熟シロネズミを用い，第 1 表に示す如き試験飼料を与えた。実 験 1 に拈いてはセルロースレペルを $5 \%$ とし，同量の供試多糖類と置換したものを試験飼料とした。実験 2 に おいてはセルロースレベル $2 \%$ 尔のままとし，糖質源である蔗糖を $5 \%$ 精製コンニャク粉で置換したものを 試験飼料とし

た。コンニャ Table 1. Diet composition

ク粉は群馬県

\begin{tabular}{|c|c|c|c|c|c|c|c|c|}
\hline \multirow{3}{*}{ Ingredient } & \multicolumn{4}{|c|}{ Experiment 1} & \multicolumn{4}{|c|}{ Experiment 2} \\
\hline & \multicolumn{2}{|c|}{$10 \%$ fat } & \multicolumn{2}{|c|}{$30 \%$ fat } & \multicolumn{2}{|c|}{$10 \%$ fat } & \multicolumn{2}{|c|}{$30 \%$ fat } \\
\hline & Cont. & Exper. & Cont. & Exper. & Cont. & Exper. & Cont. & Exper. \\
\hline Casein & 20 & 20 & 20 & 20 & 20 & 20 & 20 & 20 \\
\hline Sucrose & 60 & 60 & 40 & 40 & 63 & 58 & 23 & 18 \\
\hline Crisco & 9 & 9 & 29 & 29 & 9 & 9 & 49 & 49 \\
\hline Vitamin oila) & 1 & 1 & 1 & 1 & 1 & 1 & 1 & 1 \\
\hline Vitamin mixture ${ }^{b}$ ) & 0.85 & 0.85 & 0.85 & 0.85 & - 0.85 & 0.85 & 0.85 & 0.85 \\
\hline Choline- $\mathrm{HCl}$ & 0.15 & 0.15 & 0.15 & 0.15 & 0.15 & 0.15 & 0.15 & 0.15 \\
\hline Mineral mixturec) & c) 4 & 4 & 4 & 4 & 4 & 4 & 4 & 4 \\
\hline Cellulose & 5 & - & 5 & - & 2 & 2 & 2 & 2 \\
\hline Polysaccharides & - & 5 & - & 5 & - & 5 & - & 5 \\
\hline
\end{tabular}

産のもので50

$\%$ \%コール

で数回洗浄後

乾燥したもの,

ペクチンは和

光純薬製品の

Citrus pect-

inを用い,ア

ルギン酸は和

光純薬㜞品の

アルギン酸ナ

トリウムを用

a) One gram of vitamin oil contains 300 I. U. of vitamin A acetate, $30 \mathrm{I}$. U. of vitamin $\mathrm{D}_{2}$ and $10 \mathrm{mg}$ of $\alpha$-Tocopheryl acetate.

いた。

b) This was identical with Harper's mixture. ${ }^{15)}$

c) This was identical with Harper's mixture. ${ }^{15)}$

両実験とも脂肪源としてクリスコを用い,さらにそのレベルを变えて試験した。自由食飼育にて10日間飼育 し, 飼料摂取量括よび体重を測定した。まな実験 2 においては飼育 4 日目より後半 5 日間毎日霬を採取した。 糞は乾燥後粉末となし，ソクスレット法により総脂肪量を測定した。実験終了後断頭により屠殺し，血清およ び肝臓を採取した。トリダリセライド (以下 TG) は Van Handel \& Zilversmit 改良法 ${ }^{12)}$, リン脂質 (以下 PL) は Fiske \& SubbaRow 法 ${ }^{13)}$ とより定量した。

\section{実験結果並びに考察}

\section{1. 実験 1}

i) 体重増加量および飼料攝取量 試験動物の体重 変化は第 1 図の如くで, 10\%脂肪群，30\%脂肪群とも 供試多糖類の添加により対照群にくらべて体重増加が 劣っていた。ペクチン,コンニャク精粉,アルギン酸の 順に減少の程度が大となって物り，また高脂肪群に抒 いては10\%脂肪群においてょり減少の程度は大となっ ていた。特徴的なことは30\%脂肪群におけるコンニャ ク精粉およびアルギン酸添加群の体重の変化で, 試験 食投与後 4 日目までほとんど体重の増加が認められな
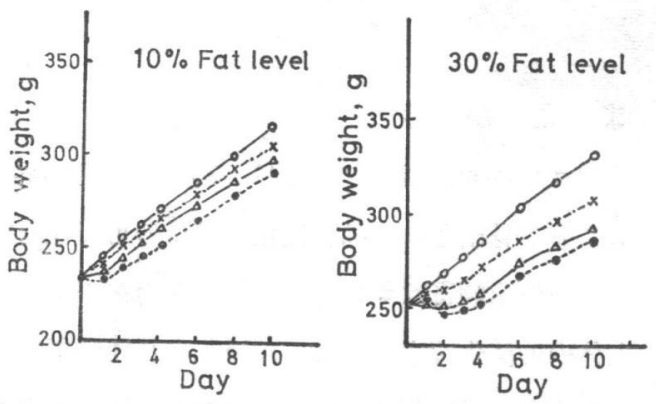

Fig. 1 Body weight gain of rats fed on various polysaccharides with different fat level

$\bigcirc-\bigcirc$ Control, $\quad \times-\cdots \times$ Pectin, $\triangle-\triangle$ Konjac flour, -...... Na-alginate 
かった。そこて゚，飼料摂取

量を前半 4 日分と後半 6 日 分とに分けてみると，第 2 表の如くで，コンニャク精 粉添加群とアルギン酸添加

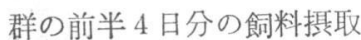
量が極端に低下していた。

これが供試多糖類群の体重 減少の主な原因と考元られ る。

ii）血清および肝臟の中 性脂肪と燐脂質 血清拉よ び肝臓の中性脂肪と燐脂質 におよぼす各種供試多糖類 の影響を調べた結果は第 3 表の如くである。

血清中性脂肪は $10 \%$ 脂肪 レベルにおいてコンニャク

精粉群のみ有意の減少をみ せたが，他の多糖類ても減 少の傾向をみせた。30\%脂 肪群ではどの多糖類を添加 しても有意の減少を示した が，これは摂取量の減少が 大きく影響している。血清 の燐脂質は両脂肪レペルに おいてコンニャク精粉とア ルギン酸をそれ艺れ投与し た時に減少を示しペクチンは影響を持たなかった。肝葴の中性脂肪と燐脂質はどの脂肪レベルでも変動を示 さなかった。

\section{2. 実験 2}

実験 1 にみられる如く, 飼料中にコンニャク精粉を添加することにより, 血清中性脂肪と燐脂質は有意な低 下を示した。そこで, その作用機構としてまず脂肪の吸収阻害の考えられるところから, 糞中への脂肪排泄に ついて検討した。

i）体重増加量および飼料摂取量 体重増加曲線を第 2 図に, 10 日間の飼育期間の前半 3 日分および後半 7 日分の飼料摂取量と体重増加量を第 4 表に示した。10\%脂肪レベルにおいてはコンニャク精粉を添加しても飼 料摂取量, 体重増加量に大きな差が認められなかったが，50\%脂肪レベルでは実験 1 でみられたと同じように 


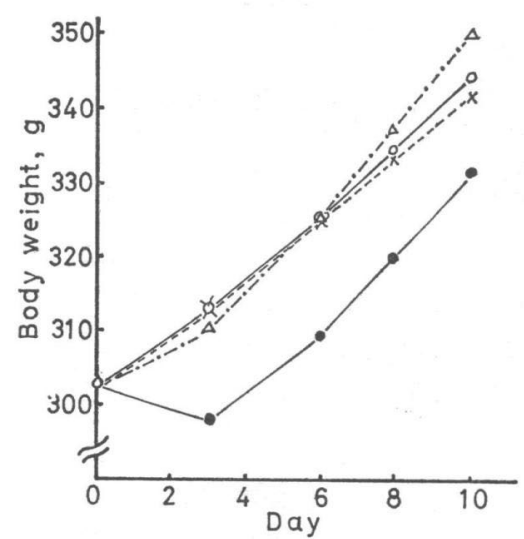

Fig. 2 Body weight gain in rats fed on Konjac flour with different fat level

$\bigcirc-\bigcirc$ Control, 10\% fat $\times \cdots . . \times$ Konjac flour, 10\% fat

$\triangle-\triangle \triangle$ Control, $50 \%$ fat

Konjac flour, 50\% Fat

最初の 3 日間において飼料摂取量 が有意に減少し，体重も著しく減 少した。しかし後半 7 日間では飼 料摂取量就よび体重増加量に差は みられなかった。
Table 4. Effect of Konjac flour on food intake and body weight gain

\begin{tabular}{|c|c|c|c|c|c|c|}
\hline \multirow{2}{*}{$\begin{array}{c}\text { Fat } \\
\text { level } \\
(\%)\end{array}$} & \multirow{2}{*}{ Group } & \multirow{2}{*}{$\begin{array}{l}\text { No. } \\
\text { of } \\
\text { rats }\end{array}$} & \multicolumn{2}{|c|}{ Food intake $(g)$} & \multicolumn{2}{|c|}{ Weight gain (g) } \\
\hline & & & $\begin{array}{l}\text { for first } \\
3 \text { days }\end{array}$ & $\begin{array}{l}\text { for last } \\
7 \text { days }\end{array}$ & $\begin{array}{l}\text { for first } \\
3 \text { days }\end{array}$ & $\begin{array}{l}\text { for last } \\
7 \text { days }\end{array}$ \\
\hline \multirow{2}{*}{10} & Control & 9 & $57.7 \pm 4.2^{1)}$ & 148. $1 \pm 9.4$ & $10.3 \pm 2.7$ & $31.3 \pm 3.2$ \\
\hline & $K$. flour & 10 & $53.3 \pm 2.1$ & 146. $9 \pm 4.8$ & $10.5 \pm 2.2$ & $29.5 \pm 2.0$ \\
\hline \multirow{2}{*}{50} & Control & 9 & 45. $7 \pm 3.2$ & $118.7 \pm 6.2$ & $7.6 \pm 2.9$ & $37.9 \pm 3.6$ \\
\hline & $K$. flour & 10 & $28.4 \pm 1.5^{2)}$ & $104.7 \pm 4.3$ & $-7.6 \pm 3.6^{2)}$ & $34.9 \pm 5.0$ \\
\hline 1) & & & & & & \\
\hline 2) & & & rent & & $\mathrm{P}<0.01$ & \\
\hline
\end{tabular}

Table 5. Effect of Konjac flour on lipids content in serum and feces

\begin{tabular}{|c|c|c|c|c|c|c|}
\hline \multirow{2}{*}{$\begin{array}{l}\text { Fat } \\
\text { level } \\
(\%)\end{array}$} & \multirow{2}{*}{ Group } & \multirow{2}{*}{$\begin{array}{l}\text { No. } \\
\text { of } \\
\text { rats }\end{array}$} & \multicolumn{2}{|c|}{ Serum } & \multicolumn{2}{|c|}{ Feces } \\
\hline & & & $\begin{array}{c}\mathrm{TG} \\
(\mathrm{mg} / \mathrm{d} l)\end{array}$ & $\begin{array}{c}\mathrm{PL} \\
(\mathrm{mg} / \mathrm{d} l)\end{array}$ & $\begin{array}{l}\text { Dry wt. } \\
\text { (g) }\end{array}$ & $\begin{array}{l}\text { Total } \\
\operatorname{lipid}(\%)\end{array}$ \\
\hline \multirow{2}{*}{10} & Control & 9 & $79.0 \pm 7.0^{1)}$ & $203 \pm 14$ & $6.7 \pm 0.4$ & 7. $8 \pm 1.0$ \\
\hline & $K$. flour & 10 & $40.4 \pm 2.5^{4)}$ & $164 \pm 21$ & $8.0 \pm 0.3$ & 16. $7 \pm 2.5^{3)}$ \\
\hline \multirow{2}{*}{50} & Control & 9 & $44.2 \pm 8.6$ & $147 \pm 15$ & 6. $0 \pm 2.0$ & 15. $0 \pm 0.3$ \\
\hline & $K$. flour & 10 & $25.5 \pm 1.6^{2)}$ & $130 \pm 7$ & $7.0 \pm 1.1$ & $18.5 \pm 0.8^{2)}$ \\
\hline
\end{tabular}

1) Mean $\pm \mathrm{SE}$

2) Significantly different from the control $\mathrm{P}<0.05$

3) Significantly different from the control $\mathrm{P}<0.01$

4) Significantly different from the control $\mathrm{P}<0.001$

ii）血清脂質および糞中への脂質排泄におよぼすコンニャク精粉添加の影響 第 5 表に示すよ5に，10\%括 よび50\%脂肪レベルに打いてコンニャク精粉添加により血清中性脂肪の著しい減少が認められた。血清燐脂質 に対しては実験 1 と異なり減少の傾向を認めたが，統計的には有意でなかった。

粪中排泄脂肪量は $10 \%$ および $50 \%$ の両脂肪レベルに扎いてコンニャク精粉の添加により有意の上昇を示し た。50\%脂肪レベルに拈いてはコンニャク精粉添加による脂肪排泄増加は比較的少ないが，これは脂肪レベル をあげることにより，対照群に脂肪排泄の相対的増加が起ったことによるものと解釈できる。

\section{考察}

難消化性多糖類の添加により動物の体重増加量は対照に比して減少した。減少の程度は多糖類の種類によっ て異なるが，飼料の脂肪レベルによっても異なることが判明した。そして体重増加量の減少忚試験期間内に一 様に起るものではなく，最初の $2 \sim 3$ 日間の体重減少が大きく，その後次第に回復を示した。そこで，飼料摂 取量をみると, 同様に最初の $2 \sim 3$ 日間における摂取量の減少が著しい。なぜ摂取量が減少するのかその理由 は明らかでないが，日数の経過と共に摂取量が増加し，体重増加に回復がみられるようになったことより，生 体はこれら多糖類に対して適応してゆくものと考元られるこの適応は多糖類の種類や脂肪のレベルによって 異なっている。そして, 低脂肪レベルでは最初の不適応による対照群と多糖類群との体重差がそのままほとん 
ど1 カ月後の体重差となって現われている。な报, 実験 1 の高脂肪群において多糖類添加により血浧の中性脂 肪拉よび燐脂質に低下がみられたが，これは後半 6 日に执いてるなお摄取量が有意に低下したために体重増加 量が有意に減少したことによるところが大きく, 多糖類とのるのの影響とは断定できない。実験 2 に扎いては $50 \%$ 高脂肪を用いたが，後半 7 日に打いてこのようなことはみられなかった。これは実験 1 と実験 2 で使用し たネズミの年令差によるもので，より老令の体重の大きい方が影響をうけにくいのかも知れない。

ところで, 高脂肪食群における体重の変動の様相は, これら多糖類による脂肪吸収に対する影響の問題を提 供すると同時により効果的な体重調整の可能性をる示唆している。

著者らの 1 人印南外協同研究者 ${ }^{1)}$ はさきにシロネズミを用い, 飼料にコレステロールと胆汁酸を添加し, さ らに供試多糖類を加えた実験において, ペクチン, アルギン酸, コンニャク精粉添加群はいずれも血清総脂肪 酸濃度の低下することを認めているが，今回は用いた 3 種類の多糖類のうちではコンニャク精粉に血清中性脂 肪の著しい低下作用のあることを見出した。

最近児玉ら ${ }^{14)}$ はコンニャクマンナンの血漿コレステロール上年抑制の作用機構はコレステロールの腸管内に おけけるセル形成阻害による吸収阻害にあることを示唆する論文を発表している。したがって，コレステロー ルと同じく脂質に分類される中性脂肪も当然, コンニャク精粉添加により吸収阻害の起ることが考えられる。 䔬中脂肪の排泄増加はそれを明示しているものである。

本実験に怙いてはコンニャク精粉を用いたが，血漿コレステロール上䄯抑制作用はコンニャク精粉中の多糖 類であるコンニャクマンナンであることが, 桐山ら ${ }^{10)}$, 辻 ${ }^{11)} に よ り$ 明らかにされているので, 本実験で得ら れた血清中性脂肪低下作用もコンニャクマンナンそのものにより行なわれているすのと推定される。

動脈硬化症にはコレステロール由来のみならず, 中性脂肪を主とする高脂血症由来のもののあることも知ら れているので, コンニャク精粉に血清中性脂肪低下作用の認められたことはコンニャク精粉めるいはコンニャ クマンナンによる動脈硬化症予防の可能性を一層示唆するものであろう。

要

約

脂肪レベルを異にした飼料にコンニャク精粉などの難消化性多糖類を加えた場合の体重増加, 血清および肝 臓のコレステロール以外の脂質成分について調べた結果

1）コンニャク精粉は飼料の脂肪レベルのいかんを問わず，血清中性脂肪に対して著しい低下作用を示す。

2）コンニャク精粉添加により粪中排泄脂肪が増加する。すなわち脂肪の吸収が妨げられることによって，血 清中性脂肪の低下が起るるのと推定される。

3）ペクチン, アルギン酸にみられた高脂肪レベルに和ける血清中性脂肪低下作用は主として摂取量の減少に よるものであろう。

4）肝臓の中性脂肪拈よび燐脂質に対してはほとんど影響をもっていない。

5）高脂肪食への難消化性多桾類の添加はより効果的な体重調節の可能性を示唆している。

終りに，本研究の一部はコンニャク研究助成金の援助によったものであることを付記して厚く感謝の意を表 します。

文献

1）辻 啓介, 大島寿美子, 松崎悦子, 中村敦子, 印南 敏, 手塚朋通, 鈴木慎次郎：栄養学雑誌, 26, 
$113(1968)$

2) Kiriyama, S., Y. Okazaki and A. Yoshida: J. Nutr., 97, 382 (1972)

3) Kiriyama, S., H. Morisaki and A. Yoshida: Agr. \& Biol. Chem., 34, 641 (1970)

4) 岸田典子, 沖增 哲: 栄養と食糧, 23, 135 (1970)

5) Wells, A. F., and B. H. Ershoff: J. Nutr., 74, 87 (1961)

6) Ershoff, B. H., and A. F. Wells: Proc. Soc. Exp. Biol. Med., 110, 580 (1962)

7) Leveille, G. A., and H. E. Sauberlich: J. Nutr., 88, 209 (1966)

8) Fischer, H., and P. Griminger: Proc. Soc. Exp. Biol. Med., 126, 108 (1967)

9) Fahrenbach, M., J., B. A. Riccardi and W. C. Grant: Proc. Soc. Exp. Biol. Med., 123, 321 (1966)

10) Kiriyama, S., Y. Ichihara, A. Enishi and A. Yoshida: J. Nutr., 102, 1689 (1972)

11）辻 啓介, 大島寿美子, 辻 悦子, 鈴木慎次郎, 印南 敏, 中村敦子, 平山昌子, 手塚朋通 : 栄盖学 雑誌，31，4号（印刷中） (1973)

12) Van Handel, E., and D. B. Zilversmit: J. Lab. Clin. Med., 50, 152 (1957)

13) Fiske, C. H. and Y. SubbaRow: J. Biol. Chem., 66, 357 (1925)

14）児玉俊明, 中井秀明, 桐山修八, 吉田 昭: 栄亘と食糧, 25, 603 (1972)

15) Harper, A. E.: J. Nutr., 68, 405 (1959)

（受付：昭和 48 年 7 月 5 日） 